\title{
Orquiectomia unilateral como tratamento de orquite associada à epididimite em equino: relato de caso
}

*Autor correspondente

e-mail: jugomidebarros@gmail.com

\section{Resumo}

Processos inflamatórios nos testículos e no epidídimo são denominados, respectivamente, orquite e epididimite, no qual geralmente ocorrem de forma concomitante. Estas alterações no trato reprodutor estão relacionadas diretamente à fertilidade do animal, podendo apresentar deficiência temporária ou permanente. A orquite e epididimite podem ser de origem infecciosa ou traumática. Os patógenos geralmente envolvidos são P. aeroginosa, Klebsiella pneumoniae, Streptococcus spp., Staphilococcus spp., B. abortus, E. coli, Mycoplasma, Ureaplasma ou Chlamydia, Protozoa. A literatura sugere administração de antiiflamatórios, antibióticos de amplo espectro, duchas frias e pentoxifilina como tratamento inicial. Caso não haja melhora, é indicada a orquiectomia unilateral. 0 inchaço e a degeneração de um testículo causados pela inflamação podem afetar o mecanismo de termorregulação local e a espermatogênese no testículo oposto pode ser prejudicada. Foi realizado atendimento a campo em um equino, macho, Brasileiro de Hipismo, 19 anos de idade, que apresentou aumento de volume e temperatura no testículo esquerdo, com sensibilidade dolorosa à palpação. Na anamnese não foi relatada ocorrência de trauma e no exame ultrassonográfico foram identificadas alterações compatíveis com orquite e epididimite. Foi instituída terapia conservativa com ceftiofur (2 mg/kg, IM, SID, 10 dias), sulfato de amicacina (5 mg/kg, IM, BID, 10 dias) e meloxicam 2\% (10 $\mathrm{mg} / \mathrm{kg}$, IV, SID, 6 dias). Sem sucesso no tratamento conservativo, o paciente foi encaminhado para o Hospital Escola Veterinário Max Planck para realizar a orquiectomia unilateral do testículo esquerdo. 0 animal foi submetido à anestesia intravenosa com triple drip (cloridrato de xilazina 0,8 mg/kg, IV; quetamina 1,5 mg/ $\mathrm{kg}$, IV; e éter gliceril guaiacol $100 \mathrm{mg} / \mathrm{ml}, \mathrm{IV}$ ). A técnica aberta foi incialmente eleita para orquiectomia, porém, durante a manipulação, não foi possível realizar a exteriorização do testículo, assim como identificar as estruturas devido à presença de aderências. A túnica vaginal se encontrava aderida ao testículo e ao epidídimo, por isso a divulsão foi parcialmente realizada e a emasculação foi efetuada na porção proximal 
do cordão espermático. Desta forma, optou-se pela orquiectomia com a técnica fechada. Institui-se no pós-operatório penicilina benzatina (20.000 UI, IM, SID, 7 dias), gentamicina (6,6 mg/kg, IV, SID, 1 dia), flunixin meglumine (1,1 mg/kg, IV, SID, 5 dias) e profilaxia com soro antitetânico (5.000 Ul, IM, dose única). Após excisão do testículo esquerdo, observou-se a presença de fibrose, aumento de volume do epidídimo e aderência das túnicas. Este material foi encaminhado para o exame histopatológico. No laudo histopatológico, identificou-se processo inflamatório crônico e ativo localizado na região da túnica albugínia, com infiltração inflamatória perivascular de linfócitos e monócitos. Notou-se, também, proliferação excessiva de tecido conjuntivo e fibras colágenas entre a túnica albugínea e o testículo. Não foram identificadas alterações no parênquima testicular. 0 paciente teve alta em 24 horas e retornou à atividade reprodutiva após 10 meses. Assim como descrito na literatura, neste relato a orquite e a epididimite se apresentaram de forma concomitante. Devido à importância do animal como garanhão, optou-se pelo tratamento conservativo com anti-inflamatório e antibióticos de amplo espectro, embora não confirmada a origem infecciosa das afecções. Neste relato, a realização da orquiectomia unilateral foi fundamental para que cessasse o processo inflamatório e o animal retornasse à atividade reprodutiva com apenas um testículo funcional.

Palavras-chave: Orquite. Epididimite. Orquiectomia. 